\title{
Seasonal Effects of Nitrogen Fertilization on Three Species of South Texas Browse Plants
}

\author{
J.H. EVERITT AND H.W. GAUSMAN
}

\section{Abstract}

We conducted a study in Kenedy County of south Texas to determine nitrogen $(N)$ fertilization effects on crude protein (CP), $P, C a, K$, and Mg contents of 3 important deer browse plants (granjeno, Celtis pallida; lime pricklyash, Zanthoxylum fagara; and bluewood, Condalia hookeri). Four $N$ fertilizer rates $(56,112$, 168 , and $224 \mathrm{~kg} N / \mathrm{ha}$ ) were applied in February 1980 to improved rangeland plots where brush was reinfesting. Control plots were nonfertilized. Vegetation samples were assayed for $\mathbf{C P}, \mathbf{P}, \mathrm{Ca}, \mathrm{K}$, and Mg contents on 5 dates: June, September, and December 1980, and April and July 1981. The CP content of plants fertilized with $112 \mathrm{~kg} \mathrm{~N} /$ ha or more was significantly higher $(P=0.05)$ than those fertilized with $56 \mathrm{~kg} \mathrm{~N} / \mathrm{ha}$ or nonfertilized. Except for lime pricklyash plants fertilized with $224 \mathrm{~kg} \mathrm{~N} / \mathrm{ha}$, the CP content of plants fertilized with 168 and $224 \mathrm{~kg} N / \mathrm{ha}$ was not significantly different from those fertilized with $112 \mathrm{~kg} \mathrm{~N} / \mathrm{ha}$. The addition of $56 \mathrm{~kg} \mathrm{~N} / \mathrm{ha}$ had no effect on the species' CP content. Nitrogen fertilization had little effect on the $\mathrm{P}, \mathrm{Ca}, \mathrm{K}$, and $\mathrm{Mg}$ contents of the species. The 3 species from both nontreated and treated plots had adequate $C P$, $\mathrm{Ca}, \mathrm{K}$, and $\mathrm{Mg}_{\mathrm{g}}$ levels for deer nutritive requirements throughout the study, but $P$ levels were generally deficient except in April 1981.

Fertilizers increase range forage quality and yield (Duncan and Hylton 1970, Rogler and Lorenz 1974). However, most fertilizer research has been conducted on herbaceous species, particularly grasses. Fewer studies have been conducted on browse plants' response to fertilization, and most of these have been conducted on game ranges. Wood and Lindsey (1967) in Pennsylvania and Abel and Gilbert (1974) in Maine found increased crude protein (CP) in deer browse in forested areas after fertilization. Anderson et al. (1974), found increased CP in wavyleaf oak (Quercus undulata) leaves after $\mathbf{N}$ fertilization on a New Mexico range.

Little information exists on the effects of fertilizer on the quality of browse plants on Texas rangelands. We are reporting the results of a south Texas study on the $\mathrm{N}$ fertilization effects on $\mathrm{CP}, \mathrm{P}, \mathrm{Ca}$, $\mathrm{K}$, and $\mathrm{Mg}$ contents of 3 important deer browse species.

\section{Materials and Methods}

This study was conducted on the H. Yturria Ranch, $13 \mathrm{~km}$ north

Authors are range scientist and supervisory plant physiologist, respectively, Agricultural Research Service, USDA, Weslaco, Texas 78596.

This study is a contribution from the Remote Sensing Research Unit, Southern Region, Agricultural Research Service, USDA, Weslaco, Texas.

Authors thank the H. Yturria Ranch personnel for their cooperation and M.A. Alaniz for his assistance in the field and laboratory.

Manuscript received Sept. 17, 1982. of Raymond ville in Kenedy County, Texas. The area is in a transition zone between the Coastal Prairies and the South Texas Plains (Gould 1975). The climate is mild with short winters and relatively warm temperatures throughout the year. The average growing season exceeds 300 days (U.S. Dep. Commerce 1970). Average annual rainfall is $68 \mathrm{~cm}$ with most rainfall occurring during thunderstorms that are unevenly distributed both geographically and seasonally. Occasionally, tropical disturbances produce heavy rainfall. September has the highest long-term monthly average. A second rainfall peak occurs in late May or early June from squallline thunderstorms. Long rainless periods may occur any time of the year.

The topography is flat to gently sloping; elevation ranges from sea level to $30 \mathrm{~m}$ (U.S. Geological Survey 7.5-minute topographic maps). The area consists primarily of chaparral-mixed grass communities (Drawe et al. 1978). Several small tracts of brushland have been bulldozed or rootplowed on the ranch allowing native grasses and herbs to become reestablished.

The experimental location was on a tight sandy loam range site with Delfina fine sandy loam soil (Aquic Paleustalfs). The brush had been bulldozed in 1977, but reinfestation was evident. The site had less than a $10 \%$ woody canopy cover. The experimental design was a randomized complete block consisting of 3 separate blocks with all treatments in each. Treatments were 4 rates of $\mathrm{N}$ (ammonium sulfate): $56,112,168$, and $224 \mathrm{~kg} \mathrm{~N} / \mathrm{ha}$, and a control (nonfertilized). Plot size was $24.4 \times 38.1 \mathrm{~m}$ with $6.1-\mathrm{m}$ wide alleys between plots. The $N$ was applied in mid-February 1980 with a rotary fertilizer distributor. The study site was enclosed by a barbed wire fence to exclude cattle. Deer, however, had access to the plots, but there was no evidence of browsing pressure. The average deer density on the Yturria Ranch was estimated to be 1/7 ha (Gary Waggerman, Texas Parks and Wildlife Department, personal communication).

Three browse species were selected for nutrient analyses: granjeno, lime pricklyash, and bluewood. All 3 species were abundant on the experimental site and were selected for study because they are important foods of the white-tailed deer (Odocoileus virginianus) in south Texas (Davis 1951, Everitt and Drawe 1974, Everitt and Gonzalez 1979, Arnold and Drawe 1979). Plants were sampled mid-monthly in June, September, and December 1980, and April and July 1981 . Plants were hand-clipped with only the outer $5 \mathrm{~cm}$ of new growth (leaves and stems) sampled. Composited samples from 12 or more plants of each species were collected from each plot, air dried at $65^{\circ} \mathrm{C}$ for 48 hours, ground in a Wiley mill through 
a 1-mm mesh screen, thoroughly mixed, and stored in sealed jars.

Duplicate plant samples for each treatment replication were analyzed for $\mathrm{CP}, \mathrm{P}, \mathrm{Ca}, \mathrm{K}$, and $\mathrm{Mg}$. The duplicate samples were averaged prior to statistical analyses. Total $\mathbf{N}$ was determined by the Kjeldahl method (Peech et al. 1947). Nitrogen levels were multiplied by 6.25 and expressed as percent $\mathrm{CP}$. Levels of $\mathrm{Ca}, \mathrm{K}$, and $\mathrm{Mg}$ were determined by atomic absorption spectrometry (Robinson 1966). Lanthanum oxide was added to $\mathrm{Ca}$ and $\mathrm{Mg}$ samples to reduce interference. Phosphorus was determined by the rapid digestion method (Bolin and Stramberg 1944).

Each plant species was analyzed separately for analyses of variance. Plant species were not combined for analyses of variance because of the generally wide range of values among species. Duncan's multiple range test was used to test the significance of mean differences at $P=0.05$ (Steel and Torrie 1960).

\section{Results and Discussion}

All nutrient content data for the 3 browse species is presented in Table 1.

\section{Crude Protein}

Nitrogen fertilization increased the CP content of the 3 species. Granjeno plants fertilized with 112,168 , and $224 \mathrm{~kg} \mathrm{~N} /$ ha had significantly higher levels of CP than control plants; for example, granjeno plants fertilized with $224 \mathrm{~kg} \mathrm{~N} /$ ha were $24 \%$ higher in CP than control plants. Lime pricklyash plants fertilized with $112 \mathrm{~kg}$ $\mathrm{N} /$ ha had significantly higher levels of CP than control plants, while plants fertilized with $224 \mathrm{~kg} \mathrm{~N} /$ ha had significantly higher levels of CP than those from the other $\mathbf{N}$ treatments. Bluewood plants fertilized with 112 and $168 \mathrm{~kg} \mathrm{~N} /$ ha had significantly higher levels of CP than plants fertilized with $56 \mathrm{~kg} \mathrm{~N} /$ ha or nonfertilized plants. Apparently, adding $56 \mathrm{~kg} \mathrm{~N} /$ ha had little influence on the $C P$ content of the 3 species. Other workers have also reported increased CP content in shrubs after $\mathbf{N}$ fertilization (Gibbens and Pieper 1962, Wood and Lindsey 1967, Anderson et al. 1974).

The CP content of the 3 species differed significantly among the 5 sampling dates. Crude protein was highest in September 1980 and/or April 1981, and lowest in December 1980 and July 1981. The higher CP content in September 1980 probably resulted from $36 \mathrm{~cm}$ of rain which fell in August 1980 during Hurricane Allen. After the heavy rainfall, the vegetation sprouted with young, tender growth.

The CP peak of April 1981 probably resulted from new spring growth. Varner et al. (1977) and Everitt and Gonzalez (1981), reported that the highest $C P$ in south Texas browse plants usually occurred during the spring.

\section{Phosphorus}

Mean P levels of lime pricklyash plants fertilized with 112,168 , and $224 \mathrm{~kg} \mathrm{~N} /$ ha were significantly lower than $P$ levels in control plants. There were no significant differences among treatment means for bluewood and granjeno. The P levels of the 3 species differed significantly among the sampling dates. Phosphorus levels of bluewood and lime pricklyash were significantly higher in April 1981 than on the other dates, while $P$ levels of granjeno were significantly higher in April 1981 and September 1980 than on the other dates. The $P$ levels of the 3 species were generally lowest in December 1980 or in July 1981. The higher $P$ levels in April support the findings of Varner et al. (1977) and Everitt and Gonzalez (1981), who reported that the $P$ content of south Texas browse species was higher during the spring.

\section{Calcium, Potassium, and Magnesium}

Calcium levels of fertilized browse plants did not differ significantly from those levels in control plants. However, $\mathrm{Ca}$ levels of the species did differ significantly among dates. The 3 species' $\mathrm{Ca}$ levels were significantly higher in December 1980 than on the other dates. This agrees with the findings of Everitt and Gonzalez (1981).

Potassium content of fertilized browse plants did not differ significantly from that of control plants, but mean $K$ levels differed significantly among the 5 sampling dates. The 3 species' $K$ levels were significantly lower in December 1980 than on the other sampling dates. Lime pricklyash and granjeno had significantly higher levels of $\mathrm{K}$ in September 1980 than on the other sampling dates, whereas bluewood's K content was significantly higher in July 1981 than on the other dates.

The addition of $\mathbf{N}$ fertilizer had little effect on the $\mathrm{Mg}$ content of the browse plants. No significant differences were found among the treatment means of bluewood and lime pricklyash. Granjeno plants fertilized with 112 and $224 \mathrm{~kg} \mathrm{~N} /$ ha had significantly lower levels of $\mathrm{Mg}$ than plants fertilized with $56 \mathrm{~kg} \mathrm{~N} /$ ha or those nonfertilized. The 3 species' Mg levels differed significantly among sampling dates, but the species did not respond alike. Lime pricklyash and granjeno's Mg content were significantly higher in September and December 1980 than on the other dates, whereas bluewood's $\mathrm{Mg}$ content was significantly higher in July 1981 than on the other sampling dates.

\section{Precipitation}

Lack of rainfall during the first 3 months after $\mathbf{N}$ fertilization may have been detrimental to plant nutrient content. After fertilization in mid-February 1980 , only $2 \mathrm{~cm}$ of measurable rainfall occurred until mid-May, when $12 \mathrm{~cm}$ of rainfall was recorded over

Table 1. Mean treatment and seasonal nutrient contents of 3 south Texas browse plants following nitrogen fertilization.

\begin{tabular}{|c|c|c|c|c|c|c|c|c|c|c|c|c|}
\hline \multirow[b]{2}{*}{ Species } & \multirow{2}{*}{$\begin{array}{r}\text { Treat- } \\
\text { ment } \\
(\mathrm{kg} / \mathrm{ha})\end{array}$} & \multicolumn{5}{|c|}{ Treatment means' } & \multirow[b]{2}{*}{ Date } & \multicolumn{5}{|c|}{ Seasonal means } \\
\hline & & $\mathrm{CP}^{2}$ & $\mathbf{P}$ & $\mathrm{Ca}$ & $\mathbf{K}$ & $\mathbf{M g}$ & & $\mathbf{C P}$ & $\mathbf{P}$ & $\mathrm{Ca}$ & $\mathbf{K}$ & $\mathbf{M g}$ \\
\hline Bluewood & $\begin{array}{r}\text { ON } \\
56 \mathrm{~N} \\
112 \mathrm{~N} \\
168 \mathrm{~N} \\
224 \mathrm{~N}\end{array}$ & $\begin{array}{l}16.2 \mathrm{c} \\
16.4 \mathrm{bc} \\
18.1 \mathrm{a} \\
18.5 \mathrm{a} \\
17.8 \mathrm{ab}\end{array}$ & $\begin{array}{l}0.17 \mathrm{a} \\
0.18 \mathrm{a} \\
0.18 \mathrm{a} \\
0.18 \mathrm{a} \\
0.17 \mathrm{a}\end{array}$ & $\begin{array}{c}1.33 \mathrm{a} \\
1.38 \mathrm{a} \\
1.20 \mathrm{a} \\
1.29 \mathrm{a} \\
1.22 \mathrm{a}\end{array}$ & $\begin{array}{l}2.57 \mathrm{a} \\
2.58 \mathrm{a} \\
2.42 \mathrm{a} \\
2.38 \mathrm{a} \\
2.43 \mathrm{a}\end{array}$ & $\begin{array}{l}0.68 a \\
0.69 a \\
0.66 a \\
0.66 a \\
0.66 a\end{array}$ & $\begin{array}{l}\text { June } 1980 \\
\text { Sept. } 1980 \\
\text { Dec. } 1980 \\
\text { Apr. } 1981 \\
\text { July } 1981\end{array}$ & $\begin{array}{l}16.8 \mathrm{~b} \\
19.7 \mathrm{a} \\
17.0 \mathrm{~b} \\
19.4 \mathrm{a} \\
14.0 \mathrm{c}\end{array}$ & $\begin{array}{l}0.17 \mathrm{c} \\
0.20 \mathrm{~b} \\
0.16 \mathrm{c} \\
0.24 \mathrm{a} \\
0.13 \mathrm{~d}\end{array}$ & $\begin{array}{l}1.34 \mathrm{~b} \\
0.99 \mathrm{~d} \\
1.56 \mathrm{a} \\
1.18 \mathrm{c} \\
1.35 \mathrm{~b}\end{array}$ & $\begin{array}{l}2.36 \mathrm{~b} \\
2.58 \mathrm{~b} \\
1.87 \mathrm{c} \\
2.53 \mathrm{~b} \\
3.03 \mathrm{a}\end{array}$ & $\begin{array}{ll}0.64 & \mathrm{bc} \\
0.62 & \mathrm{c} \\
0.72 & \mathrm{~b} \\
0.58 \mathrm{c} \\
0.80 \mathrm{a}\end{array}$ \\
\hline Lime pricklyash & $\begin{array}{r}\text { ON } \\
56 \mathrm{~N} \\
112 \mathrm{~N} \\
168 \mathrm{~N} \\
224 \mathrm{~N}\end{array}$ & $\begin{array}{l}15.3 \mathrm{c} \\
15.4 \mathrm{bc} \\
16.4 \mathrm{~b} \\
16.3 \mathrm{bc} \\
17.5 \mathrm{a}\end{array}$ & $\begin{array}{l}0.24 \mathrm{a} \\
0.22 \mathrm{ab} \\
0.21 \mathrm{a} \\
0.21 \mathrm{a} \\
0.22 \mathrm{ab}\end{array}$ & $\begin{array}{l}1.22 \mathrm{a} \\
1.25 \mathrm{a} \\
1.20 \mathrm{a} \\
1.14 \mathrm{a} \\
1.22 \mathrm{a}\end{array}$ & $\begin{array}{l}1.60 \mathrm{a} \\
1.57 \mathrm{a} \\
1.64 \mathrm{a} \\
1.59 \mathrm{a} \\
1.54 \mathrm{a}\end{array}$ & $\begin{array}{l}0.39 \mathrm{a} \\
0.38 \mathrm{a} \\
0.40 \mathrm{a} \\
0.41 \mathrm{a} \\
0.37 \mathrm{a}\end{array}$ & $\begin{array}{l}\text { June } 1980 \\
\text { Sept.1980 } \\
\text { Dec. } 1980 \\
\text { Apr. } 1981 \\
\text { July } 1981\end{array}$ & $\begin{array}{l}15.6 \mathrm{~b} \\
17.8 \mathrm{a} \\
14.3 \mathrm{c} \\
18.1 \mathrm{a} \\
15.0 \mathrm{bc}\end{array}$ & $\begin{array}{l}0.18 \mathrm{c} \\
0.22 \mathrm{~b} \\
0.17 \mathrm{c} \\
0.29 \mathrm{a} \\
0.23 \mathrm{~b}\end{array}$ & $\begin{array}{l}1.20 \mathrm{~b} \\
1.02 \mathrm{c} \\
1.88 \mathrm{a} \\
0.96 \mathrm{c} \\
0.97 \mathrm{c}\end{array}$ & $\begin{array}{l}1.64 \mathrm{~b} \\
1.76 \mathrm{a} \\
1.35 \mathrm{~d} \\
1.56 \mathrm{c} \\
1.62 \mathrm{bc}\end{array}$ & $\begin{array}{ll}0.33 & b \\
0.46 & a \\
0.46 & a \\
0.35 & b \\
0.35 & b\end{array}$ \\
\hline Granjeno & $\begin{array}{r}\text { ON } \\
56 \mathrm{~N} \\
112 \mathrm{~N} \\
168 \mathrm{~N} \\
224 \mathrm{~N}\end{array}$ & $\begin{array}{l}20.5 \mathrm{~b} \\
21.6 \mathrm{~b} \\
25.3 \mathrm{a} \\
25.5 \mathrm{a} \\
27.1 \mathrm{a}\end{array}$ & $\begin{array}{l}0.21 \mathrm{a} \\
0.22 \mathrm{a} \\
0.25 \mathrm{a} \\
0.25 \mathrm{a} \\
0.24 \mathrm{a}\end{array}$ & $\begin{array}{l}3.64 \mathrm{a} \\
3.58 \mathrm{a} \\
3.31 \mathrm{a} \\
3.56 \mathrm{a} \\
3.34 \mathrm{a}\end{array}$ & $\begin{array}{l}1.86 \mathrm{a} \\
1.74 \mathrm{a} \\
1.82 \mathrm{a} \\
1.82 \mathrm{a} \\
1.85 \mathrm{a}\end{array}$ & $\begin{array}{l}1.02 \mathrm{a} \\
1.02 \mathrm{a} \\
0.96 \mathrm{a} \\
1.00 \mathrm{ab} \\
0.95 \mathrm{~b}\end{array}$ & $\begin{array}{l}\text { June } 1980 \\
\text { Sept. } 1980 \\
\text { Dec. } 1980 \\
\text { Apr. } 1981 \\
\text { July } 1981\end{array}$ & $\begin{array}{l}25.4 \mathrm{~b} \\
29.3 \mathrm{a} \\
18.1 \mathrm{c} \\
27.4 \mathrm{ab} \\
19.7 \mathrm{c}\end{array}$ & $\begin{array}{l}0.23 \mathrm{~b} \\
0.28 \mathrm{a} \\
0.20 \mathrm{bc} \\
0.29 \mathrm{a} \\
0.17 \mathrm{c}\end{array}$ & $\begin{array}{l}2.90 \mathrm{c} \\
3.88 \mathrm{~b} \\
5.18 \mathrm{a} \\
2.34 \mathrm{~d} \\
3.12 \mathrm{c}\end{array}$ & $\begin{array}{l}1.84 \mathrm{bc} \\
2.09 \mathrm{a} \\
1.47 \mathrm{~d} \\
1.93 \mathrm{~b} \\
1.75 \mathrm{c}\end{array}$ & $\begin{array}{l}0.83 \mathrm{c} \\
1.15 \mathrm{a} \\
1.17 \mathrm{a} \\
0.78 \mathrm{~d} \\
1.02 \mathrm{~b}\end{array}$ \\
\hline
\end{tabular}

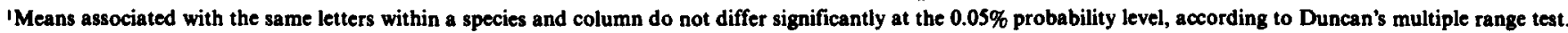
${ }^{2} \mathrm{CP}=$ Crude protein. 
a 1-week period. Drought conditions prevailed from June-August 1980 until after Hurricane Allen. Above-normal precipitation was recorded on the study area thereafter until July 1981 . Although no volatilization measurements were made, it was observed that the ammonium sulfate pellets lay on the ground for a considerable time before dissolution. Consequently, some $\mathbf{N}$ may have been lost by volatilization. Hull (1963) reported that up to $50 \%$ of $\mathrm{N}$ broadcast on grassland soils in the ammonium form can volatilize. Although the CP content of $\mathrm{N}$-fertilized browse was significantly increased, we believe that a greater increase in $\mathrm{CP}$ and possibly other nutrient levels would have occurred with more rainfall during the early months of the study.

\section{Conclusions and Management Implications}

We found that browse plant quality, as measured by CP content, was increased by $\mathrm{N}$ fertilization. However, a $\mathrm{N}$ application at a 112 $\mathrm{kg} \mathrm{N} /$ ha rate was needed to significantly increase the CP content of bluewood, lime pricklyash, and granjeno. Applications of 168 and $224 \mathrm{~kg} \mathrm{~N} / \mathrm{ha}$ rates did not generally enhance the CP content of browse plants over those with the $112 \mathrm{~kg} \mathrm{~N} /$ ha rate. The CP content of the 3 species, from both fertilized and nonfertilized plots, always exceeded the $13 \%$ minimum level recommended for maximum gain and reproduction in white-tailed deer (French et al. 1956, Murphy and Coates 1966, Verme and Ullrey 1972). Nitrogen fertilization had little or no effect on the $\mathrm{Ca}, \mathrm{K}$, and $\mathrm{Mg}$ content of browse plants. The $\mathrm{Ca}, \mathrm{K}$, and $\mathrm{Mg}$ content of the 3 species always exceeded the requirements for deer and other ruminants (Magruder et al. 1957, Maynard and Loosli 1969, Verme and Ullrey 1972). Since the nonfertilized browse plants contained adequate levels of $\mathrm{CP}, \mathrm{Ca}, \mathrm{K}$, and $\mathrm{Mg}, \mathrm{N}$ fertilization is probably not an important management tool for south Texas browse plants. If managers do desire to use $\mathrm{N}$ fertilizer to increase $\mathrm{CP}$ levels, our results indicate that rates need not exceed $112 \mathrm{~kg} \mathrm{~N} / \mathrm{ha}$.

The $P$ levels of the 3 species were often below the $0.25 \%$ minimum requirement level reported for deer (Magruder et al. 1957). Phosphorus is a critical nutrient in deer food plants in south Texas and elsewhere in the United States (Urness et al. 1971, Short 1977, Everitt and Gonzalez 1981). Unfortunately, we found that, for some unknown reason, the $\mathbf{P}$ content in lime pricklyash decreased with $\mathrm{N}$ fertilization. We assumed that the sulfate from ammonium sulfate would have only a slight influence on nutrient solubility in the soil with a pH of about 8.0 (Jerry Jacobs, Soil Conservation Service:personal communication). If the sulfate had any measurable effect, it should have increased the $P$ availability. Therefore, other $\mathbf{N}$ and $\mathbf{P}$ fertilizer rates and combinations need to be evaluated on browse plants to determine if their $\mathbf{P}$ content deficiencies for animals can be alleviated.

\section{Literature Cited}

Abel, D.H., and F.F. Glbert. 1974. Nutrient content of fertilized deer browse in in Maine. J. Wildl. Manage. 38:517-524.

Anderson, B.L., R.D. Pieper, and V.W. Howard, Jr. 1974. Growth response and deer utilization of fertilized browse. J. Wildl. Manage. 38:525-530.

Arnold, L.A., Jr., and D.L. Drawe. 1979. Seasonal food habits of whitetailed deer in the South Texas Plains. J. Range Manage. 37:175-178.

Bolin, 0.W., and W.E. Stramberz. 1944. Rapid digestion method for determination of phosphorus. Indus. and Engin. Chem. Analyst. Ed. 16:345-346.
Davis, R.B. 1951. The food habits of white-tailed deer on the cattle stocked, liveoak-mesquite ranges of the King Range, as determined by analyses of deer rumen contents. Unpub. M.S. Thesis, Texas A\&M Univ. College Station.

Drawe, D.L., T.W. Box, and A.D. Chamrad. 1978. Plant communities of the Welder Wildlife Refuge. Contr. 5, Series B (revised). Welder Wildlife Found., Sinton, Texas.

Duncan, D.A., and L.O. Hylton, Jr. 1970. Effects of fertilization on quality of range forage. p. 57-62. In: Range and Wildlife Habitat Evaluation- $A$ Research Symposium, H.A. Paulsen, Jr., and E.H. Reid (eds.) USDA. Misc. Pub. 1147.

Everitt, J.H., and D.L. Drawe. 1974. Spring food habits of the white-tailed deer in the South Texas Plains. J. Range Manage. 27:15-20.

Everitt, J.H., and C.L. Gonzalez. 1979. Botanical composition and nutrient content of fall and early winter diets of white-tailed deer in south Texas. Southwestern Natur. 24:297-310.

Everitt, J.H., and C.L. Gonzalez. 1981. Seasonal nutrient content in food plants of white-tailed deer on the South Texas Plains. J. Range Manage. 34:506-510.

French, C.E., L.C. MeEwen, N.D. MaGrudzer, R.H. Inrram, and R.W. Swift. 1956. Nutrient requirements for growth and antler development in white-tailed deer. J. Wildl. Manage. 20:221-232.

Glbbens, R.P., and R.D. Pieper. 1962. The response of browse plants to fertilization. California Fish and Game. 48:268-281.

Gould, F.W. 1975. Texas plants-A checklist and ecological summary. Texas Agr. Exp. Sta. MP-585.

Hull, A.C. 1963. Fertilization of seeded grasses on mountainous rangelands in northeastern Utah and southeastern Idaho. J. Range Manage. 16:306-310.

Magruder, N.D., C.E. French, L.C. McEwen, and R.W. Swift. 1957. Nutritional requirements of white-tailed deer for growth and antler development. II. Experimental Results of the Third Year. Pa. Agr. Exp. Sta. Bull. 628.

Maynard, L.A., and J.K. Loosli. 1969. Animal nutrition. McGraw-Hill, New York.

Murphy, D.A., and J.A. Contes. 1966. Effects of dietary protein on deer. Trans. N. Amer. Wildl. and Natur. Resources Conf. 31:129-138.

Peech, M.L., A. Dean, and J.F. Reed. 1947. Methods of soil and water analyses for fertility investigations. USDA. Circ. 754.

Roblson, J.W. 1966. Atomic absorption spectroscopy. Marcel Dekker Press, New York.

Rocler, G.A., and R.J. Lorenz. 1974. Fertilization of mid-continent range plants. p. 231-254. In: Forage Fertilization, D.A. Mays (ed.). Am. Soc. Agron., CSSA, SSSA, Madison, Wis.

Short, H.L. 1977. Food habits of mule deer in a semidesert grass-shrub habitat. J. Range Manage. 30:206-209.

Steel, R.G.D., and J.H. Torrie. 1960. Principles and procedures of statistics. McGraw-Hill Book Co., Inc., New York.

United States Department of Commerce. 1970. Climatological summary. Brownsville, Texas.

Umees, P.J., W. Green, and R.K. Watkins. 1971. Nutrient intake of deer in Arizona chaparral and desert habitats. J. Wildl. Manage. 35:221-231.

Varner, L.W., L.H. Blankenahip, and G.W. Lynch. 1977. Seasonal changes in nutritive value of deer food plants in south Texas. Proc. Annual Conf. S.E. Ass. Fish and Wildlife Agencies. 31:99-106.

Verme, L.J., and D.E. Ullrey. 1972. Feeding and nutrition of deer. p. 275-291. In: The Digestive Physiology and Nutrition of Ruminants. Vol. 3. D.C. Church, Ed. Dept. Animal Sci., Oregon State Univ., Corvallis. Wood, G.W., and J.S. Lindsey. 1967. The effect of forest fertilization on the crude protein, calcium, and phosphorus content of deer browse in a mixed oak forest. Pa. Coop. Wildl. Res. Unit Pap. 126. 